Libretos

\title{
My Dream of Europe
}

\section{Martin R. Dean}

Abstract: How the Swiss see, classify and judge Europe depends on how they see themselves. The external image is a consequence of the self-image. Switzerland as a small but beautiful island. This self-description is deeply inscribed in the country's memory. In contrast, my writing is closely linked to a European invention: the big city, the old European cities in which the Enlightenment and liberal thought produced a culture of progress, liberality and tolerance. Paris and London, Lisbon and Berlin, Amsterdam and Vienna

Keywords: Europe, european cities

Zusammenfassung: Wie die Schweizer Europa sehen, einstufen und beurteilen, hängt davon $a b$, wie sie sich selbst sehen. Das Fremdbild ist eine Konsequenz des Selbstbildes. Die Schweiz als kleine, aber feine Insel. Diese Selbstbeschreibung ist tief in die Erinnerung des Landes eingeschrieben. Im Gegensatz dazu ist mein Schreiben ist eng verknüpft mit einer europäischen Erfindung: der Grossstadt, die alten europäischen Grossstädte, in denen die Aufklärung und die liberalen Gedanken eine Kultur des Fortschritts, der Liberalität und der Toleranz hervorgebracht haben. Paris und London, Lissabon und Berlin, Amsterdam und Wien.

Schlüsselwörter: Europa, europäischen Grossstädte 
In 1997, when I wanted to write a typical Swiss scene for my novel "The Ballad of Billie and Joe" I went to Melide, a small town in Ticino, situated in the southern part of the country. Here you are encouraged to walk at hip height through a three dimensional small model of Switzerland. "Swiss Miniature" reduces Switzerland to its touristic sights.

Excerpts from my novel "La Ballade de Billie et Joe:

Mais Joe a une relation compliquée à la Suisse. Dans l'hôtel en forme de boîte, sur la haute falaise surplombant le lac, où ils sont descendus après avoir fui leur ville, Billie commençait déjà à rêver de cette Suisse miniature. De ce modèle réduit avec les reproductions des châteaux, des monuments et des curiosités de l'Helvétie. Avant d'avoir vraiment pris la fuite, elle voulait déjà rebrousser chemin pour venir ici. Il était debout à la fenêtre, les mains enfoncées dans les poches de son pantalon et regardait de l'autre côté, vers l'Italie. Que veux-tu que je fasse, demande-t-il à Billie, dans cette maison de poupée nationale. Encore un hommage à ton enfance, parce que tu ne peux vraiment dire adieu à rien ni à personne....

Le pays miniature est comme un jardin japonais. Le regard glisse par-dessus des toits qui lancent des reflets clairs et se faufile par de petites portes et fenêtres. Le bon Dieu rit au- dessus des petits pignons. Joe fume et ne sait pas où faire tomber sa cendre. Tout est sacrément trop étroit pour lui ici, trop tracé d'avance, mais Billie saute sans effort d'un petit château à l'autre. Elle se faufile dans chaque petite maison comme Alice au Pays des Merveilles et dit, imagine, imagine, Joe, nous sommes les propriétaires du château de Chillon, seuls pour des centaines d'années dans ces appartements silencieux, la brume, tu rêves, imagine Joe. Billie rêve toujours de petites choses dans lesquelles elle peut se faufiler et se cacher. Des petites boîtes et des coquillages et des labyrinthes d'escargots qui l'avalent. Ah Billie, elle lui fait joyeusement signe de la main comme pour dire adieu à ce monde et disparaît. Elle redevient enfant, juste maintenant, où il est si fier de la voir courageuse, il est fier de partir avec une femme, peut-être pour toujours. Billie et son patriotisme de maison de poupée.'

It is striking that the all the surrounding European hinterland such as French Alsace, German South Baden, Italian Lombardy as well as Austria is missing. The "Swiss Miniature" model reveals all touristic clichés about Switzerland.

How the Swiss see, classify and judge Europe depends on how they see themselves. The historian Jakob Tanner describes the patriotic image of Switzerland as follows: Switzerland is seen as an independent island that has to defend itself against a hostile environment, namely the EU. This Switzerland overestimates itself as a role model for direct democracy. It is thought to possess an intact landscape and the Alps are portrayed as an extraordinary nature reserve. At the center of Swiss life 
stand the farmers, whose values are expressed in sports through swinging, skiing, and horn playing and in cultural activities through yodelling, singing and hiking. Switzerland is a small but beautiful island. "This self- description”, writes Tanner, "is deeply inscribed in the culture of memory".

Real Switzerland is different. "The Dörfli (villlage) mentality, Tanner continues, "became a cloak of invisibility that turned the 'secret empire' (Lorenz Stucki) of Swiss capitalism invisible.

In real Switzerland the peasants are subject to merciless economic forces and are more than generously subsidized. Their share in the care of the landscape is modest. The groundwater is endangered due to over-fertilization of the soil. The paradigm of direct democracy forms a challenge for many citizens, whose decisions are often guided less by understanding but by resentment. This is fertile ground for the terrible simplifications of right-wing parties. Real Switzerland functions as operational base for many global corporations in the areas of asset management, commodity trading, pharmaceuticals and agribusiness. These same corporations are often criticized widely. Switzerland lives well with this false self-image as long as it does not interfere with business.

Switzerland is neither worse nor better than surrounding European countries. Were its self-image different, Switzerland would understand itself as part of Europe. With imports and exports to the EU, it would have every reason to do so. In addition, more people with a migration background live in Switzerland than in other countries. They constitute about 30\% of the population and are largely well integrated. Thanks to its quadrilingualism, Switzerland is well prepared for the exchange with people from other countries and cultures. Also, no other people travel as much as the Swiss.

\section{What does Europe mean to me?}

As a German speaking writer, Europe provides me with a pool of stories, within which I can continue to write. Since hellenistic times the European tradition has collected discourses from Jewish, Arab and African sources.

My writing does not stem from a particular landscape. However, it is,closely linked to the metropolitan European tradition. By metropolitan I do not mean such cities as New York, Shanghai, or Rio de Janeiro, but am referring to the old European cities of Paris, London, Lisbon, Berlin, Amsterdam and Vienna, where the Enlightenment and liberal thought produced a progressive, liberal, and tolerant culture.

It is these cities with their public squares that are typically European for me. In the large and small squares, the agora, the public life of the polis is negotiated and the intellectual conversation continues in its cafés, bistros and coffee houses. The museums, concert halls, landscapes and gardens express the aesthetic of a society. Of course, my Europe is a product of the Enlightenment and my birth hall is the Room of Enlightenment in the British Museum. This European and anti-colonial Enlightenment 
spans from the Marques de Pombal to Voltaire, from Diderot to Kant and the Swiss writer Rousseau. My favorite writers, as well, are characterized by typical European images of men and women, by utopias and distortions: Fernando Pessoa and Robert Walser, Franz Kafka and Hans Henny Jahnn, Thomas Mann and Marieluise Fleisser, Antonio Lobo Antunes and Annie Ernaux.

About London I wrote in my essay collection Bowing Before Mirrors:

Thanks to its history, London has remained a model for a multiethnic society. London, Paris or Amsterdam, the "mother cities" of former colonial empires, have experience in dealing with strangers, today they are - at least this may be one beneficial consequence of colonialism - mixing laboratories. They possess sufficient historical substance not to lose face in the erosive process of globalization.

And about Paris, where, beside my hometown Basel, I have spent most of my time:

In a dream that has accompanied me all my life, this city exists once again. Completely and completely, not a stone is missing. In this dream I am an inhabitant of this city, I am at home here. I always dream this dream when the longing for life is undermining me. When I dream that life could have been different. ${ }^{2}$

My Europe remains a dream. It is a project that, in spite of tourism and digitalization, we must try to continue to complete.

\section{Notes}

' Martin R. Dean (1997), The Ballad of Billie and Joe, Edition Circe, Strassbourg. (Deutsch, Hanser Verlag, München)

${ }^{2}$ Martin R. Dean (2015), Bowing Before Mirrors: Essays about the Self and the Other, Verlag Jung und Jung, Salzburg/Wien. 